\title{
MÁRIO DE ANDRADE: UM ARQUIVO DE SABERES SOBRE A LÍNGUA DO/NO BRASIL, DE LÍVIA LETÍCIA BELMIRO BUSCÁCIO ${ }^{1}$
}

Maria Iraci Sousa Costa Universidade Federal de Santa Maria - UFSM , Santa Maria, RS, Brasil

A referida tese inscreve-se no campo teórico da História das Ideias Linguísticas na sua articulação com a Análise de Discurso. O objetivo da autora é analisar as discursividades sobre a língua no Brasil no funcionamento da autoria e do arquivo discursivo em Mário de Andrade, através de uma leitura das correspondências. A autora parte do pressuposto de que o funcionamento da autoria, em seu efeito de unidade e contensão do discurso em um nome próprio (PÊCHEUX, 1988; HAROCHE, 1984), incide na organizaçáo de um arquivo discursivo. $\mathrm{O}$ arquivo discursivo organizado pela autora consiste nas correspondências entre Mário de Andrade e autores que ocupam o lugar social de quem pode/deve dizer sobre a língua, como, por exemplo, o lugar do filólogo, do gramático, do literato, do professor, dentre outros. Uma vez estabelecido o arquivo discursivo, a autora lançou mão de recortes, tendo em vista a batalha por um discurso sobre a língua ao dizer sobre a escrita literária, promovida no nome de autor a partir de lugares discursivos onde se inscrevem posiçôes em tensão sobre a língua do/ no Brasil. A autora aponta vários lugares ocupados por Mário de Andrade: estudante, literato, professor de música, de cultura brasileira, filólogo, etnógrafo, chefe do Departamento de cultura, tradutor, "turista aprendiz", escritor e leitor de cartas: intelectual, homem de letras. Do mesmo modo, também são diversos os lugares ocupados por seus correspondentes, sendo trazidos pelo recorte do arquivo Sousa da Silveira, Manuel Bandeira, Pio Lourenço Corrêa. A autora considera também as condiçôes de produção de Mário de Andrade e seus missivistas. Com base em Orlandi (2002), a autora considera que a formação do lugar intelectual de brasileiro alinha-se às condiçóes de produção do estado e da língua nacional no Brasil, submetida a uma formação discursiva positivista. Tendo em vista tais condiçóes de produção, a autora busca compreender o lugar discursivo como uma

1 Tese orientada pela Profa. Dra. Vanise Gomes de Medeiros, co-orientada pelo Prof. Dr. José Luis Jobim, defendida em 2014, na Universidade Federal Fluminense. 
categoria constituída na transição do lugar social para a materialidade da língua no arquivo discursivo. No caso da relação com um nome de autor, o lugar discursivo reforça o efeito de legitimidade sobre o dizer produzido pela funçáo-autor. Contudo, pela própria movência do discurso, o efeito de unidade e de legitimidade produzidos pelo lugar de onde um autor fala é esvanecido pela inscrição das posiçóes discursivas em tensão na teia de dizeres sobre a língua que dáo corpo à correspondência de Mário de Andrade. A autora sustenta também uma compreensão da correspondência enquanto materialidade discursiva, pela qual é possível averiguar em uma prática de "escrita de si" (FOUCAULT, 1992) a dissipação do efeito de unidade discursiva do sujeito no deslizamento do que chamamos a língua da correspondência. Ademais, considera, a partir de Colombat, Fournier e Puech (2010), que a escrita pode ser entendida como um saber metalinguístico, por veicular representações sobre a língua ao reportar-se à linguagem. Desse modo, a autora sustenta, com a análise do arquivo, que o dizer sobre a escrita literária, ao mobilizar discursividades sobre a língua, configura uma forma de saber metalinguístico. Segundo a autora, pelo funcionamento do discurso sobre a língua do/no Brasil vinculado à funçáo-autor, emerge uma veiculaçáo de saberes metalinguísticos, a partir de posições discursivas em tensão, transitando entre formaçôes discursivas lusitana, brasileira e positivista, constitutivas da memória da língua brasileira. A autora conclui, com isso, que Mário de Andrade, autor e arquivo, pode ser entendido como um acontecimento discursivo na hiperlíngua brasileira, instaurando e reatualizando a memória da língua no Brasil. 